\author{
R. S. Zeigler \\ Kansas State University, Manhattan
}

\begin{tabular}{|c|}
\hline Agricultural Biotechnology \\
\hline Reducing Poverty in Developing Countries
\end{tabular}

Agriculture is a small, if essential, component of the economies of the developed countries of the world. Not surprisingly, most people in these countries have little or no contact with primary food production and processing, and experience little direct or immediate impact from a change in production practices. In the United States, at least, food is inexpensive and is broadly considered to be safe and benign, with the production and delivery chains taken for granted. Debates surrounding the introduction of new technology such as transgenic crops or food irradiation tend to focus on remotely possible but conceivably serious negative impact on the consumer. An unspoken argument often embedded in such debates is that any increase in health risk to the consumer is unacceptable when food is plentiful and cheap, especially when producers or agribusiness are the principal beneficiaries. The separation of consumers from food production also tends to perpetuate a romantic vision of small-scale agriculture in harmony with the land. Transgenic crops and animals are portrayed as threatening this ideal. Thus, in developed countries, the debate around agricultural biotechnology tends to focus on the safety of foods, the impact of the crops on the environment, and to a lesser extent, the fate of rural society.

The situation in developing countries is strikingly different, as agriculture is an intimate part of most peoples' lives and food security is only a dream for millions of the poor. For example, agriculture provides $70 \%$ of employment in sub-Saharan Africa, and two-thirds of the population of Asia and sub-Saharan Africa is rural (74). The percentage of gross domestic product contributed by agriculture in low-income countries is from 4 to almost 15 times that in high-income countries (79). In Asia and Africa, 25 and $35 \%$, respectively, of regional gross domestic product is from agri-

Dr. Zeigler's address is: Department of Plant Pathology, Kansas State University, Manhattan 66506-5502

E-mail: rzeigler@ksu.edu

Publication no. D-2001-0404-01F

๑) 2001 The American Phytopathological Society culture (1). Food is expensive and can account for 50 to $70 \%$ of household income for the poor, rural or urban (11), and malnourishment of children remains unconscionably high, exceeding $25 \%$ in many countries (Fig. 1). Poverty continues to be a serious problem (Fig. 2), despite great improvements in many areas, and health, especially children's, is deficient $(71,72)$. Migration of rural poor into urban areas continues unabated (74), despite the dire circumstances that many will confront. These apparently are more attractive than abject poverty in a rural setting.

A major point of contention around agricultural biotechnology in developing countries involves intellectual property issues and the role of transnational seed and chemical companies in the creation and sale of technologies to small farmers. Until recently, the policy discussions on agricultural biotechnology in developing countries focused more on which technologies to adopt and how, rather than on questions of low-probability food safety risks, possible environmental impact, and an idyllic farm community (47). Recent policy implementation in three influential countries (Brazil, India, and Kenya) has been more along the precautionary lines of Europe and Japan, rather than on the more permissive lines of the United States and Canada. It is interesting to note that adoption of these technologies is being restrained in these developing countries in the name of biosafety and environmental impact, policy areas that previously have not been high priorities (47). Opposition to development of appropriate agricultural biotechnology targeting problems in developing countries often comes from nongovernment organizations (NGOs) whose agendas are often set by political bases and constituencies outside of developing countries.

A comprehensive overview of agricultural biotechnology of relevance to developing countries is impossible in this type of article. For example, Johanson and Ives (27) list over 100 different projects underway in the United States alone for a dozen or so African crops. For that reason, I focus on only a few crop-related technologies that are at or near deployment stage, or offer the potential for enormous change in crop productivity. Because the future of a large portion of the developing world will be determined by the extent to which the needs of the poor are met, I will focus only on technologies that relate directly to increasing productivity or improving nutrition of the poor. I do not discuss technologies that are somewhat further from deployment, yet of major potential impact, such as edible vaccines for a range of diseases afflicting people in developing countries, direct or indirect transgenic tools for animal improvement and health, or edible immune system enhancers for management of HIV. Nor do I discuss the exciting potential to add value to a wide range of food and export crops. A good general introductory presentation of the range of opportunities for agricultural biotechnology to contribute to economic growth and development in developing countries is presented by Serageldin and Persley (58).

The causes of poverty, malnourishment, and disease are enormously complex and do not lend themselves to complete resolution with the application of a few new technologies. Nonetheless, based on past success, there is reason to expect that improved agricultural technology can help improve even the poorest people's lives. An important lesson from the Green Revolution is that new technologies generated from agricultural biotechnology must contribute to sustainable productivity increases within, and compatible with, existing agroecologies and socioeconomic systems. Gordon Conway refers to this integration as a "Doubly Green Revolution" (8).

I devote special attention to South Asia and sub-Saharan Africa, where poverty and malnutrition are particularly serious. Africa by and large missed benefiting from the Green Revolution that helped in transforming the economies of Asia and Latin America (25). Perhaps more than the rest of the developing world, Africans can ill-afford to miss the potential contribution that biotechnology can make to helping solve some of their more intractable problems.

\section{Dimensions of Poverty}

Population and poverty in developing countries. Global population growth rates have begun to decline; however, rates are still high in a number of developing countries (Table 1). The large proportion of 
children in today's population assures that total population growth in lower income countries will continue well into the middle of the present century. During the first decades of this century, predicted global population growth rates will add almost 90 million people per year. How will we feed 90 million new people per year, every year? Most of these will be in poor, developing countries. Fertility rates are declining but remain high in some of the world's poorest and most populous areas (Table 2). Over the short to medium term, these trends are irreversible and will require significant increases in food production if mass starvation is to be avoided. For example, demand for rice, a staple food throughout much of the developing world, is expected to increase by more than $55 \%$ over the next 30 years $(10,24,35)$.

Impact of urbanization on agriculture and on diets of the poor. It is expected that by 2020 , more than half of the people living in developing countries, or over 3.5 billion, will be in large cities (74). This migration is not surprising, considering the dire conditions faced by rural populations. In many African countries, rural populations have more than doubled the percentage of people living below the poverty line compared with urban areas (79). The migration trends and the level of poverty suggest that rural life in developing countries is intolerable for significant portions of the population. This shift requires that a relatively declining rural population will have to produce even more food for swelling urban populations.

Urban poor tend to depend more on starchy staples and consume relatively less leafy vegetables. Arable land area per capita has been declining in most low-income regions, and land area under irrigation has remained fairly stagnant over the last two decades (Table 3). As economies expand, the better land and water are diverted to urban and industrial uses (86). Again, agriculture will have to become more efficient just to support a growing and increasingly urban population.

Global poverty levels. Because population growth continues, the absolute number of people living in serious poverty (income of less than $\$ 1$ per day) is increasing in some areas $(49,63)$, even as the percentage of poor in the population declines. This is most serious in South Asia and subSaharan Africa, with these two areas accounting for over two-thirds of the people living in serious poverty (Fig. 2). It is projected that even in 2020, sub-Saharan Africa will have average per capita income levels below one US\$ per day (49). The impact of poverty on human well-being is devastating, especially for women and children. Infant mortality (deaths in the first year of life) remains near 10\% in subSaharan Africa and South Asia, and under5 mortality is over $15 \%$ in sub-Saharan

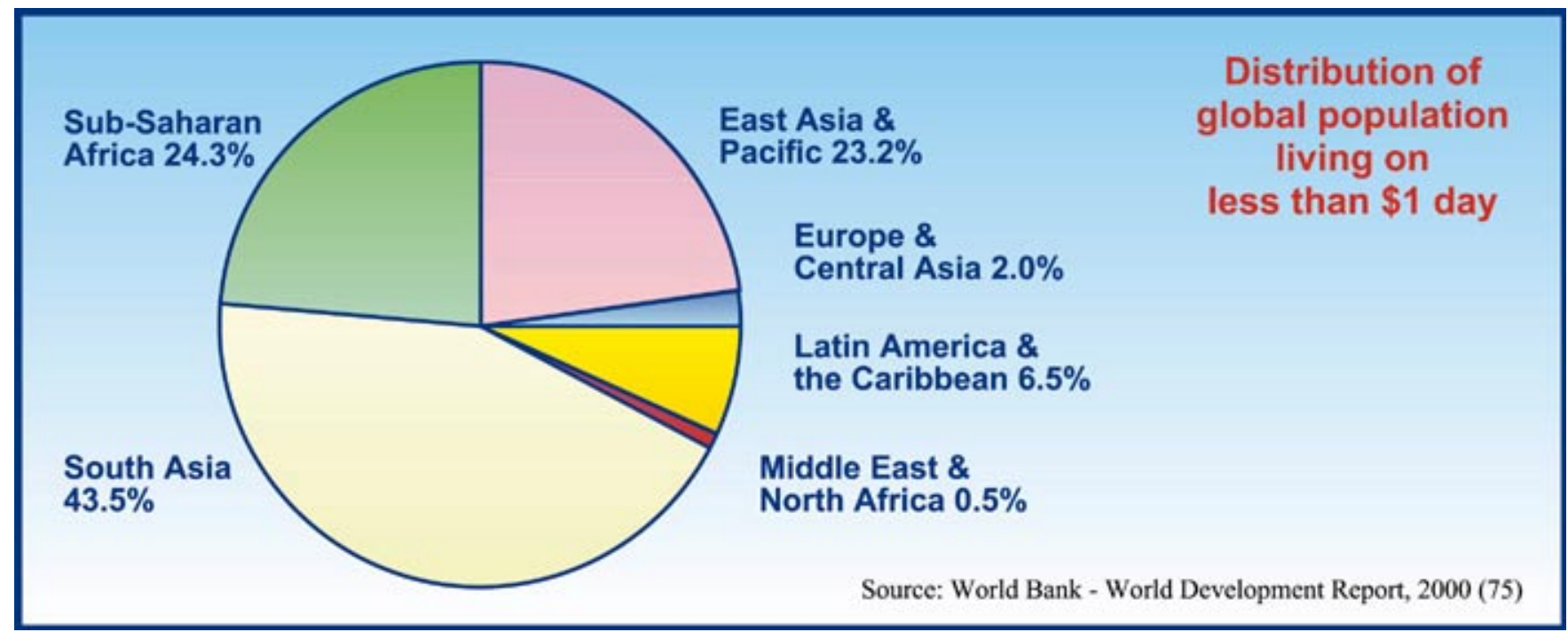

Fig. 1. Regional distribution of global population living on less than US\$1 per day.

\section{Prevalence of anemia in preschool children and pregnant women by region}

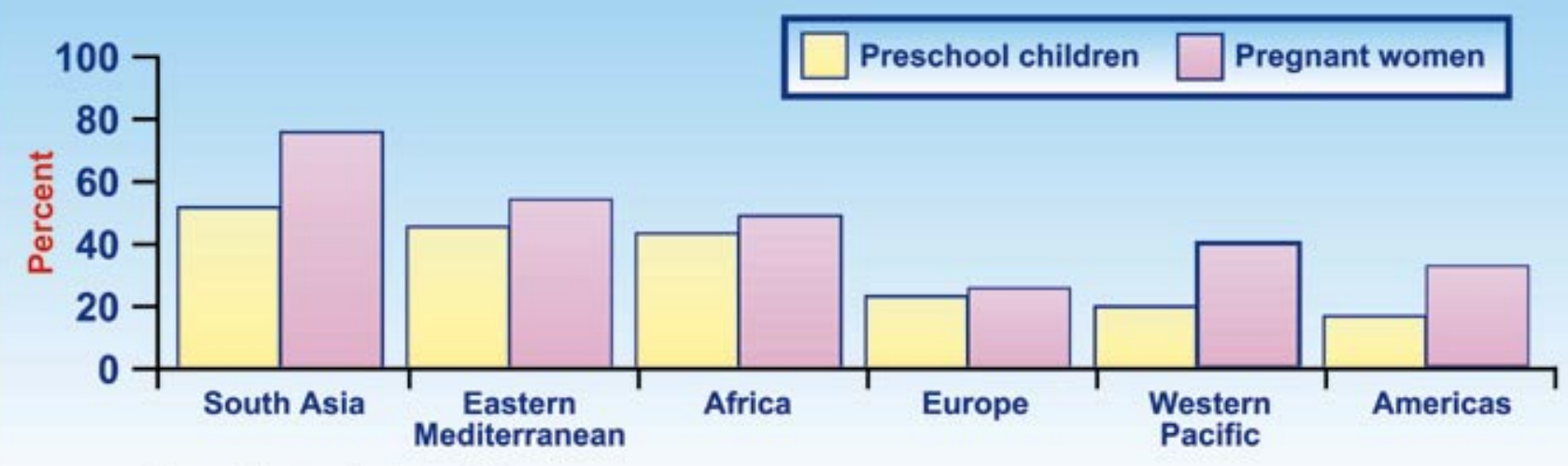

Source: Pinstrup-Anderson (45)

Fig. 2. Percentage of women and children suffering from iron-deficiency anemia, by region. 
Africa (Table 2). Twenty-four of the 25 countries with the highest under-5 mortality rates are in sub-Saharan Africa (72). While these death rates have dropped dramatically over the last 20 years in all lowincome areas, they remain unacceptably high, with South Asia and sub-Saharan Africa 15 and 25 times greater, respectively, than high-income countries $(71,72)$.

Malnutrition in low-income regions. South and Southeast Asia and sub-Saharan Africa are expected to account for $75 \%$ of

Table 1. Population, population growth rates and percentage of population composed of children in low and middle income regions of the world.

\begin{tabular}{|l|l|l|l|l|}
\hline & & \multicolumn{2}{|c|}{$\begin{array}{l}\text { Average annual } \\
\text { growth rate (\%) }\end{array}$} & $\begin{array}{l}\text { \% Children } \\
<15 \text { yrs. }\end{array}$ \\
\hline Regions & $\begin{array}{l}\text { Total } \\
\text { (Millions, 1999) }\end{array}$ & $\mathbf{1 9 8 0 - 9 0}$ & $\mathbf{1 9 9 0 - 9 9}$ & \\
\hline Low and middle ineome & & & & \\
\hline East Asia \& Pacific & $1,836.9$ & 1.6 & 1.3 & 33 \\
\hline Europe \& Central Asia & 475.3 & 0.9 & 0.2 & 33 \\
\hline Latin America \& Caribbean & 509.2 & 2.0 & 1.7 & 37 \\
\hline Middle East \& North Africa & 290.9 & 3.1 & 2.2 & 41 \\
\hline South Asia & 1.329 .3 & 2.2 & 1.9 & 40 \\
\hline Sub-Saharan Africa & 642.3 & 2.9 & 2.6 & 47 \\
\hline High Income & 890.9 & 0.6 & 0.6 & 33 \\
\hline World & 5974.7 & 1.7 & 1.0 & 37 \\
\hline
\end{tabular}

Source: World Bank - World Development Report, 2000 (75)

Table 2. Female ferility and child mortality rates in low and middle ibsome regions of the world

\begin{tabular}{|l|l|l|l|l|l|l|l|}
\hline & \multicolumn{2}{|l|}{$\begin{array}{l}\text { Total fertility rate } \\
\text { (Births per woman) }\end{array}$} & \multicolumn{2}{l|}{$\begin{array}{l}\text { Infant mortality rate } \\
1,000 \text { live births }\end{array}$} & \multicolumn{2}{l|}{$\begin{array}{l}\text { Under } 5 \text { mortality } \\
\text { rate } 11,000\end{array}$} \\
\hline Low and middle income & 1980 & 1998 & 1980 & 1998 & 1980 & 1998 \\
\hline East Asia \& Pacific & 3.0 & 2.1 & 55 & 35 & 82 & 43 \\
\hline Europe \& Central Asia & 2.5 & 1.6 & 41 & 22 & $\ldots$ & 26 \\
\hline Latin America \& Caribbean & 4.1 & 2.7 & 61 & 31 & 78 & 38 \\
\hline Middle East \& North Africa & 6.2 & 3.5 & 95 & 45 & 136 & 55 \\
\hline South Asia & 5.3 & 3.4 & 119 & 75 & 180 & 87 \\
\hline Sub-Saharan Africa & 6.6 & 5.4 & 115 & 92 & 188 & 151 \\
\hline High Income & 1.8 & 1.7 & 12 & 6 & 15 & 6 \\
\hline World & 3.7 & 2.7 & 80 & 54 & 123 & 75 \\
\hline
\end{tabular}

Source: UNICEF - State of the World's Children 2000 (66)

Table 3. Irrigated land as a percentage of total crop area and arable land, percapita, in low and middle income countries.

\begin{tabular}{|l|l|l|l|l|}
\hline \multirow{2}{*}{ Regions } & \multicolumn{2}{|c|}{$\begin{array}{l}\text { Irrigated land } \\
\text { (\% of crop land) }\end{array}$} & \multicolumn{2}{|l|}{$\begin{array}{l}\text { Arable land } \\
\text { (Hectares per capita) }\end{array}$} \\
\hline & $1979-81$ & $1995-97$ & $1979-81$ & $1995-97$ \\
\hline Low and middle income & 21.9 & 21.9 & 0.20 & 0.21 \\
\hline East Asia \& Pacific & 37.0 & 36.3 & 0.11 & 0.11 \\
\hline Europe \& Central Asia & 11.6 & 10.4 & 0.14 & 0.60 \\
\hline Latin America \& Caribbean & 11.6 & 13.5 & 0.32 & 0.28 \\
\hline Middle East \& North Africa & 25.8 & 35.5 & 0.29 & 0.21 \\
\hline South Asia & 28.7 & 39.7 & 0.23 & 0.16 \\
\hline Sub-Saharan Africa & 4.0 & 4.2 & 0.32 & 0.25 \\
\hline High income & 9.8 & 11.2 & 0.46 & 0.41 \\
\hline World & 17.8 & 19.2 & 0.24 & 0.24 \\
\hline
\end{tabular}

Source: World Bank - World Development Report, 2000 (75)

the world's calorie- and protein-deficient, malnourished children by 2020 (Fig. 3) (63). Poor children and women are also seriously afflicted by dietary deficiencies. The most widespread and serious of these are vitamin A and iron deficiencies. Iron deficiency anemia afflicts approximately 3.5 billion people in developing countries worldwide, with young children and pregnant women being particularly affected in Africa and Asia (Fig. 1). The impact of iron deficiency includes anemia and death in pregnant women, low birth weight, and reduced cognitive abilities and development in children, and generally increased susceptibility to infectious diseases in all affected people (81). In diets dominated by cereals, roots, and tubers, iron absorption is reduced by up to two-thirds compared with a balanced diet containing the same amount of iron (7). Iron deficiencies in the diet are exacerbated by poorly balanced diets, particularly those deficient in vitamin $\mathrm{A}(9,16)$.

Vitamin and micronutrient deficiencies among the poor. Vitamin A (retinol), the first vitamin discovered, is essential in early embryogenesis and for the proper functioning of the immune system, the retina, and mucous membranes. It is either absorbed directly from animal products or synthesized from plant carotenoids (e.g., beta-carotene). An estimated 280 million children suffer moderate to severe vitamin A deficiency, resulting in 1 to 3 million deaths annually and over 300,000 cases of childhood blindness each year $(70,80)$. Indeed, vitamin A deficiency is the principal cause of childhood blindness in developing countries. Vitamin A deficiency also exacerbates susceptibility to and effects of diarrheal diseases, malaria, and other diseases common in developing countries. Diets heavily dominated by roots, tubers, and cereals, and consequently very low in green vegetables, animal protein, and dairy products are associated with vitamin A deficiency. In both vitamin $\mathrm{A}$ and iron deficiencies, adults of both genders exhibit reduced energy levels and lethargy. Although green leafy vegetables can provide adequate supplies of vitamin $\mathrm{A}$, and to a lesser extent iron, the long-term feasibility of providing a sufficient supply for very large and poor urban populations is not at all certain $(51,80)$, particularly for the millions of urban poor. Major vitamin A supplement programs are underway or proposed for the poorest developing countries with high child mortality. Longer term solutions include increasing the vitamin A content of staple and processed foods (70).

Parasitic and infectious diseases in developing countries. Parasitic and infectious diseases compound the misery imposed by malnutrition and poverty (71). However, the disease-nutrition link is not limited to lowered resistance to pathogens. In southern Africa and China, there are hot spots of esophageal cancer that are correlated with consumption of moldy maize 
$(36,82)$. In these regions, maize is the main staple food, with a popular form of consumption being a home-brewed beer. Maize in tropical and subtropical regions is often badly affected by ear-rotting fungi, especially Fusarium spp. (54). Rotted ears in southern Africa are preferentially used to brew beer; but in years of food shortage, they may be consumed directly in porridge (39).

Poverty in developing countries. The poor either are unable to produce sufficient and nutritionally diverse food because they lack the land, or are unable to purchase sufficient nutritious food because they lack money. Their diets, already lacking in vitamins and minerals, tend to be dominated by what they can afford to meet their minimum caloric needs: cereals, roots, and tubers. These further inhibit absorption of essential nutrients. The resulting deficiencies reduce the productivity of the workforce and cause debilitating lifelong conditions that further drain the meager resources of poor families. Clearly, external intervention is needed to break the cycle.

\section{Contribution of Agricultural Technology}

It is probably true that with present technology the world has the capacity to produce sufficient food for all on a simple tonnage basis. It does not follow, however, that the problem is simply one of food distribution. The poor lack the economic resources even to purchase food that is locally available. Major long-term structural changes in society are required to improve the lot of the poor. These include better educational opportunities for women, which have been shown to be major factors in reducing fertility, improved drinking water and public health facilities, improved urban and rural infrastructure, and more equitable access to financial institutions and markets $(63,79)$. Even in optimistic scenarios, such changes will not have ma- jor impact over the next generation. Thus, in the absence of more immediate interventions, those born into poverty today most likely will die in poverty. What can be done in the short-to-medium term to help alleviate poverty while societies hopefully invest in poverty-reducing infrastructure and policies?

In the face of looming famine throughout Asia during the 1960 s, critics of development aid claimed there was no way to avoid mass starvation and social upheaval in areas like South Asia and Africa, given then-current production trends (48). With the introduction of semidwarf rice and wheat varieties and associated fertilizer and irrigation technologies, which became known as the "Green Revolution," their dire predictions did not materialize. Today, Asia is home to about $70 \%$ more people than during the 1960s, but because of a near-doubling of rice production, per capita consumption is about $15 \%$ higher. Even the "basket cases," where future food production was predicted to be hopelessly deficit, have produced surpluses (13). Global rice production has been steadily increasing at about $2.8 \%$ per year since the 1960 s, of which about $2.2 \%$ is from yield increases and the remainder from area expansion. Indeed, the real price of wheat and rice in global trade has been steadily declining $(24,35)$, with real domestic retail prices dropping dramatically in South Asia (10). Even early critics of the Green Revolution now acknowledge that its benefits have spread through all social strata in areas where enabling policies have been adopted along with new technologies $(22,60)$. However, production growth rates have declined sharply over the last decade in developing countries as production area expansion has nearly ceased, and yield growth rates in tropical cereals seem to be slowing, raising the concern that new technological innovations are required (10).

Two components of a short-term, or interim, tactical approach to breaking the cycle of poverty should be to reduce the price of food by increasing supply (see 10 for an expanded discussion of this) and to improve the nutritional value of food that the poor can afford. The high proportion of the poor's income that goes to the purchase of staple foods means that any drop in price is equivalent to an increase in income. Economists refer to food in this case as a "wage good." A drop in the price of a staple food, made possible by productivity increases or decreases in the unit cost of production, makes the poor "richer" and frees income for other uses such as diversification of their diet, education, or medicine. Increases in productivity will also be required to meet the needs of growing urban populations, but the food must be produced on the same lands in use today, and be more water efficient. Significant increases will have to come from marginal lands (86). I will introduce two areas where biotechnology can contribute to increased productivity: (i) reduced losses to pests and pathogens and (ii) increases in photosynthetic efficiency in rice.

Elimination of nutrient and protein deficiencies by improving the quality of affordable foods should improve the overall health of the population and contribute to increased productivity and income generation (81). I will introduce two areas where biotechnology can make major contributions to improved nutritional content of staple foods: (i) improved vitamin $\mathrm{A}$ and (ii) iron content of rice. Finally, I will briefly present a case where existing transgenic Bt-maize lines might contribute to alleviating a serious public health problem in southern Africa, in addition to reducing losses to stem borers.

\section{Improving Productivity in Staple Crops}

Two means of raising productivity are to lower losses (i.e., express existing yield potential) and to raise yield potential.

\section{Percentage of malnourished children, 1995-2020}

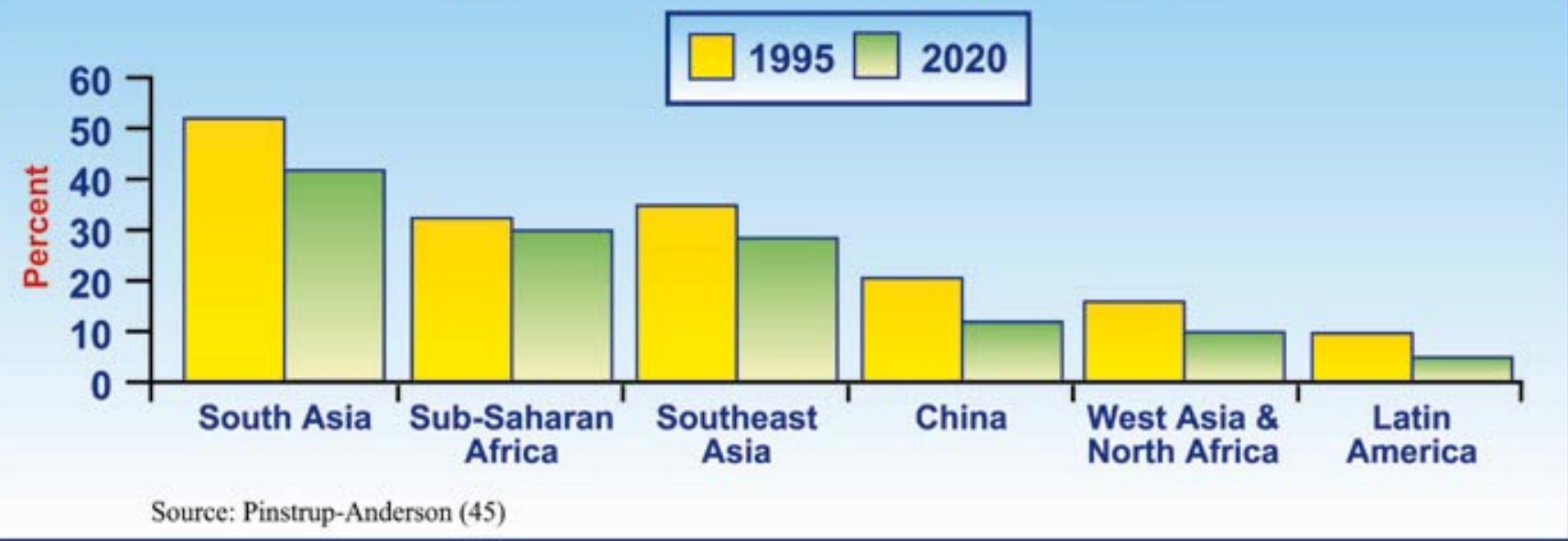

Fig. 3. Percentage of malnourished children by region. 
Pathogens and insects continue to take a significant portion of the harvest of staple and high-value horticultural crops. Many pests and pathogens, especially in the tropics, continue to resist the best efforts of agricultural science to develop resistance and/or effective management schemes to reduce losses. The ability of genetically engineered resistance to reduce losses in developed countries to previously intractable problems has been convincingly demonstrated in both temperate and tropical agriculture. Losses caused by the European corn borer (Ostrinia nubilalis) in the U.S. Corn Belt have been reduced significantly with incorporation into corn hybrids of $\mathrm{Bt}$ toxin (of bacterial origin), which is lethal to Lepidoptera larvae (45). The papaya industry in Hawaii has been revived with the incorporation of resistance in papaya to the potyvirus Papaya ringspot virus. This resistance was achieved by transforming papaya with the gene coding for the coat protein of the virus (18). I will examine one case where biotechnology is being applied to reduce losses to another potyvirus in sweet potato in eastern Africa.

Major gains in yield potential in wheat and rice were achieved in the 1960s with the incorporation of genes for semidwarf plant type. Although steady progress has been made in improving yield and quality, major gains in yield potential by engineering new plant types has been a frustrating undertaking. Attention is now turning toward engineering the physiology of yield. I will briefly explore the potential for transforming one of our most important staple cereals, rice, in order to significantly increase its photosynthetic potential.

Reducing losses to Sweet potato feathery mottle virus (SPFMV). Sweet potato (Ipomoea batatas) is a staple food for millions throughout the world, ranking fifth in fresh weight production after wheat, rice,

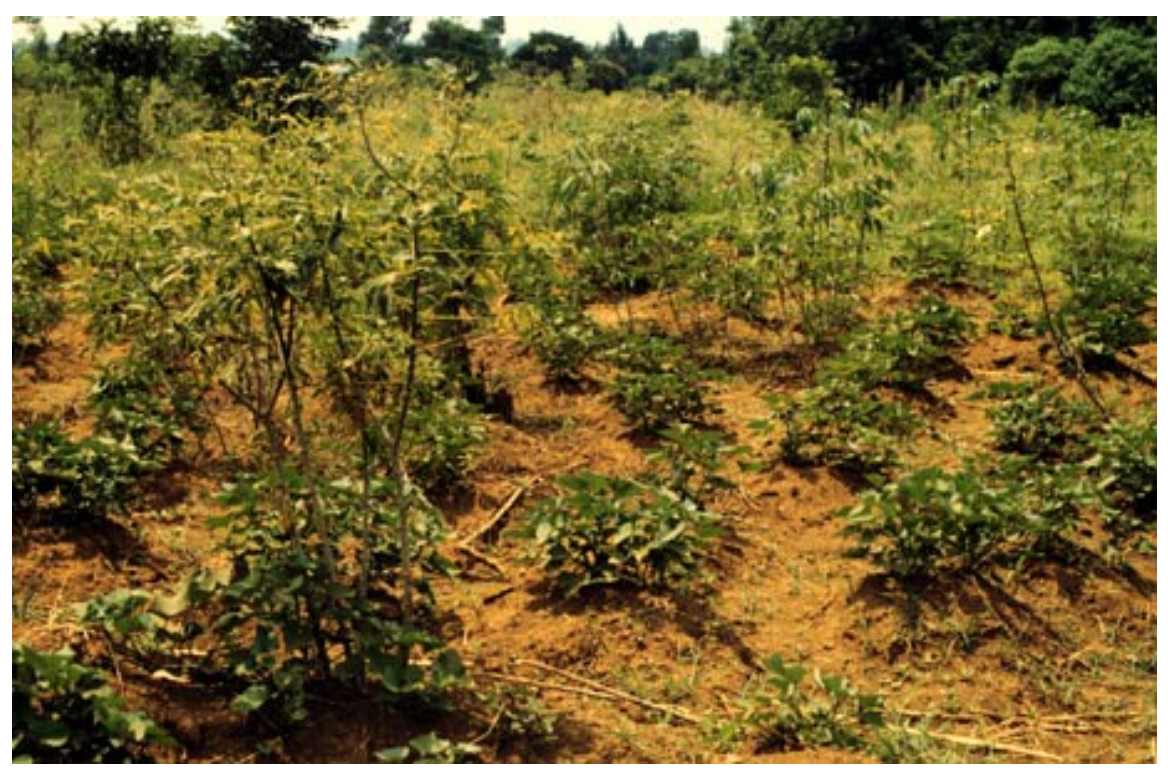

Fig. 4. Sweet potato growing under cassava severely affected by African cassava mosaic disease (photo credit: E. Carey).

maize, and cassava (14). It is especially important in poor regions of China and east-central Africa, where it is increasing in importance following losses in cassava and plantain to African cassava mosaic disease (Fig. 4) and black sigatoka, respectively (27). SPFMV, an insect-vectored potyvirus, is a worldwide problem and is among the most serious diseases of sweet potato in east-central Africa $(3,7,42)$. Symptoms include yellow mottling of the leaves and cracking of the roots (Fig. 5). Losses are in the form of reduced yields and lower tuber quality. The disease is particularly problematic because sweet potatoes are propagated from cuttings, and although disease-free planting material can be produced via meristem culture (59), in most regions there are no tissue culture facilities to produce sufficient clean planting material.

It is common for sweet potatoes to be infected by one or more viruses in addition to SPFMV, referred to as sweet potato virus disease (SPVD) $(28,84)$. Yield losses to sweet potato viral disease complex can exceed $30 \%$ in China $(83,84)$. Infection of sweet potato by a single virus usually results in only mild symptom development in East Africa. However, infection by other viruses when SPFMV is present results in severe symptoms, presumably by facilitating replication of the other viruses. Thus, incorporation of SPFMV resistance could reduce the impact of other viruses as well. While sources of SPVD and SPFMV resistance are available $(3,4,26)$, sexual hybridization and classical plant breeding of sweet potato are difficult, and most developing countries tend to devote fewer resources to root and tuber crop improvement than to cereal improvement.

At least three groups (Kenya Agricultural Research Institute [KARI], in collaboration with Monsanto and the USAID-

572 Plant Disease / Vol. 85 No. 6 funded Agricultural Biotechnology Support Project at Michigan State University; the Center for Plant Biotechnology Research, Tuskegee University; and the Japan International Research Center for Agriculture) are working to incorporate SPFMV resistance by transforming sweet potato with the viral coat protein gene. Both the Japanese and the Kenyan groups have succeeded in creating transgenic plants expressing the coat protein and showing good levels of resistance, in terms of symptom expression, yield, and detectable virus titer $(25,57,76)$. However, the mechanism is not known by which virus replication is reduced. In other cases for which potyvirus resistance is obtained by transformation with a coat-protein gene, the resistance is due to post-transcriptional gene silencing.

The Kenyan experience is particularly instructive, in that there was close collaboration between the private sector (Monsanto) and the public sector (KARI and Michigan State University) that resulted in making the proprietary technology of the private sector freely available for use in sweet potato in Africa. Biosafety and field testing protocols have been worked out for Kenya (76), and on-station field trials were initiated in late 2000 (46). Nonetheless, it took more than 2 years from the time the technology was initially offered to KARI for these protocols to be worked out (47).

While a simple fix to difficult problems is attractive, caution should be exercised to avoid raising expectations too high for a complete solution to the SPFMV problem. It is not yet clear that resistance to SPFMV alone will significantly reduce symptoms of SPVD. The SPFMV case raises specific technical issues around sweet potato and several issues of broader implication for biotechnology in developing countries. From a strictly technical perspective, it remains to be proved how well this resistance will hold up in nature. Are there variants within SPFMV populations that are virulent to the transformed sweet potatoes? With infection by multiple viruses being the norm, under realistic field situations, how effective will viral coat protein resistance be to only one of them? The answers to these questions should be sought as part of the early evaluation protocols for the transgenic lines. Although it is expected that transgenic vegetatively propagated sweet potato should be stable, this too, should be explicitly evaluated. More generally, how will the performance of these materials depend upon management of planting stock from season to season? How many clones will be required over environmentally heterogeneous growing areas? Will repeated transformations be required for every new variety, and if so, how can such capacity be built in regions with massive competing demands for resources both within and outside the agricultural research sector? Finally, what is the impact on quality and agronomic traits 
of importance to consumers and farmers? Most of these question in one form or another are relevant to most transgenic crops varieties.

It is admirable for a large transnational corporation to allow free access to its proprietary technology for applications of direct benefit to the poor. Can we expect, indeed, is it fair to demand, that this will be the norm for similar technologies in the future? Sustainable progress in developing improved disease-resistant cultivars, including resistance conferred by transgenic techniques, will depend upon having strong classical breeding programs. It will be important for policymakers and governments to understand that transgenic approaches generally serve only to bolster breeding programs and that the impact of the new technologies will depend upon the strength of breeding and seed delivery programs, be they public or private.

Raising yield potential in rice. The benefits from incorporating novel genes for pathogen and insect resistance into our major crop species should increase their productivity in the near term. But since production increases of $50 \%$ or more are required, these increases will not reach the levels required to meet projected demand increases. The yield potential of our principal food crops will have to be increased if we are to avoid production area expansion into ecologically fragile or valuable lands. Tropical lowland rice is an ideal candidate for such research, as the best farmers are already achieving yields equal to the best obtained on experimental fields (29), and there is mounting evidence that these yield levels can be sustained (12). However, rice demand projections suggest that we will have to increase the yield potential of rice from its historical limit of 10 t/ha (29) to something closer to $15 \mathrm{t} / \mathrm{ha}$ if we are to avoid further area expansion into uncultivated lands (61). There is reason to believe that over the long term we can redesign our crops to dramatically improve their yield potential.

Photosynthesis in rice has been shown to be suboptimal under the high light saturation and high temperature conditions common where it is widely grown (23). Unlike maize and sorghum, the other important domesticated tropical $\mathrm{C} 4$ cereals, rice has $\mathrm{C}_{3}$ photosynthesis. $\mathrm{C}_{4}$ cereals dramatically reduce photorespiration by concentrating $\mathrm{CO}_{2}$ in organic acids via phosphoenolpyruvate carboxylase (PEPC) in mesophyll cells, then later releasing the $\mathrm{CO}_{2}$ in characteristic bundle sheath cells (Kranz anatomy) where the concentration of $\mathrm{CO}_{2}$ is higher than ambient. This higher concentration of $\mathrm{CO}_{2}$ yields a relatively lower concentration of $\mathrm{O}_{2}$ and lower catalytic losses of Rubisco, an important $\mathrm{N}$ store. $\mathrm{C}_{4}$ plants show greater water and $\mathrm{N}$ use efficiency because of their ability to maintain high rates of photosynthesis under higher temperatures with greater stomatal closure and reduced Rubisco losses (55).

It is unlikely that in the near-term it will be feasible to completely re-engineer the rice plant to be fully $\mathrm{C}_{4}$ because of the many anatomical and biochemical features that would have to be changed simultaneously. However, it seems possible to engineer key features of $\mathrm{C} 4$ pathways into rice, especially since many of the elements are already present $(31,32,68)$. "Primitive" $\mathrm{C}_{4}$ plants (e.g., the aquatic Hydrilla verticilata) have the key enzymatic components, including PEPC, pyruvate orthophosphate dikinase (PPDK), and NADPmalic enzyme (NADP-ME). Under low $\mathrm{CO}_{2}$ conditions, $H$. verticilata shifts to a $\mathrm{C}_{4}$ photosynthesis, even without Kranz anatomy. PEPC incorporates $\mathrm{C}$ into the $\mathrm{C}_{4}$ organic acid malate, which is then released in the chloroplast as $\mathrm{CO}_{2}$ from the action of NADP-ME. This raises the $\mathrm{CO}_{2}$ concen- tration sufficiently to significantly reduce photorespiration (52).

Recently, rice plants have been successfully transformed to carry maize PEPC and PPDK (2,31). Plants over-expressing maize PEPC or PPDK have shown higher rates of photosynthesis and higher leaf concentrations of $\mathrm{CO}_{2}$. Maize PEPC transgenic rice plants grown in the field also showed lower photorespiration and reduced photoinhibition of photosynthesis. Thus, it seems possible to greatly improve the photosynthetic efficiency of rice without engineering its leaf anatomy (40). Lower $\mathrm{N}$ requirement per unit yield and better water-use efficiency could improve yields in less-favored, water-limited environments and for resource-poor farmers. Even rice growing in favorable irrigated environments could produce well under only intermittent irrigation, rather than continuous flooding, thus reducing water
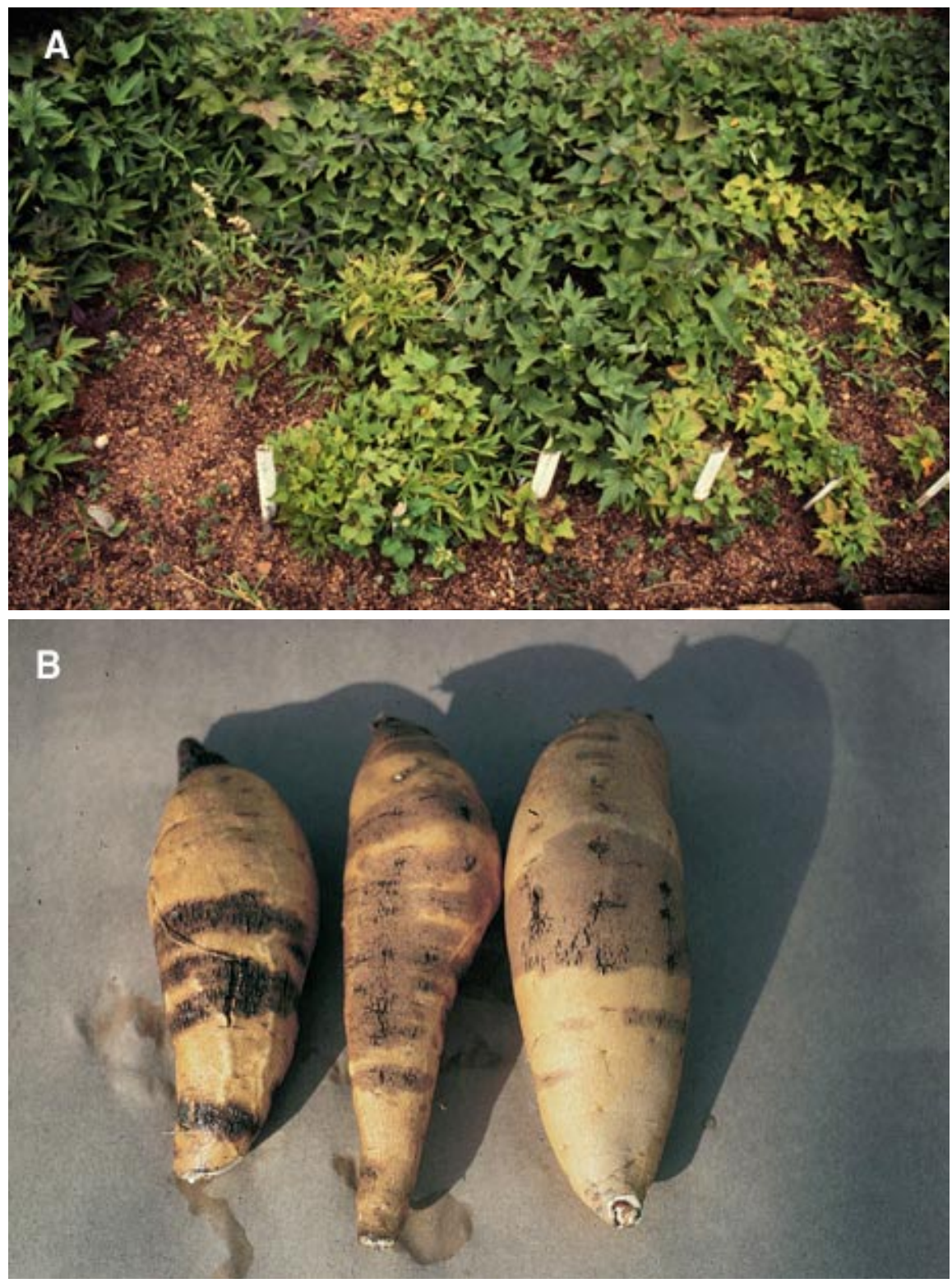

Fig. 5. Symptoms of Sweet potato feathery mottle virus. A, Foliar symptoms (photo credit: E. Carey). B, Cracked root symptoms (photo credit: W. Willis). 
requirements. With the generation of large mutant collections in rice (16) and the potential of large-scale comparative functional genomics between rice and maize, the potential for significant progress in this ambitious approach is far greater than would have been predicted only a few years ago (68).

\section{Improving Nutritional Value of Crops}

The most seriously limiting nutrient deficiencies worldwide are iron, iodine, and vitamin A $(73,81)$. Deficiencies are caused not only by shortages in the diet, but also by a diet that impedes absorption of the little that is ingested. Approximately half of the global population, primarily in developing countries, depends on rice as a staple food (34); however, it is deficient in both vitamin A and iron. While food additives have been promoted for many years as a solution to vitamin and mineral defi- ciencies, and some programs have been successful over the medium term, it is not clear that this is a sustainable strategy or, in some cases, even safe $(34,80)$. The following examples illustrate how genetically determined traits from phylogenetically very distant organisms can be incorporated to improve the nutritional value of some of our most basic staple foods.

High-vitamin A rice. The rice pericarp is rich in vitamins, oils and some minerals; but it is removed during the milling and polishing process. The grain must be polished after the hull is removed because the oils will rapidly become rancid, rendering the grain inedible. The remaining endosperm does not contain vitamin A or its carotenoid precursors (e.g., beta-carotene) from which animals synthesize vitamin A. Carotenoids are red, green, and yellow plant membrane pigments involved in photosynthesis. In 1985, early in the Rockefeller Biotechnology Program, the signifi-

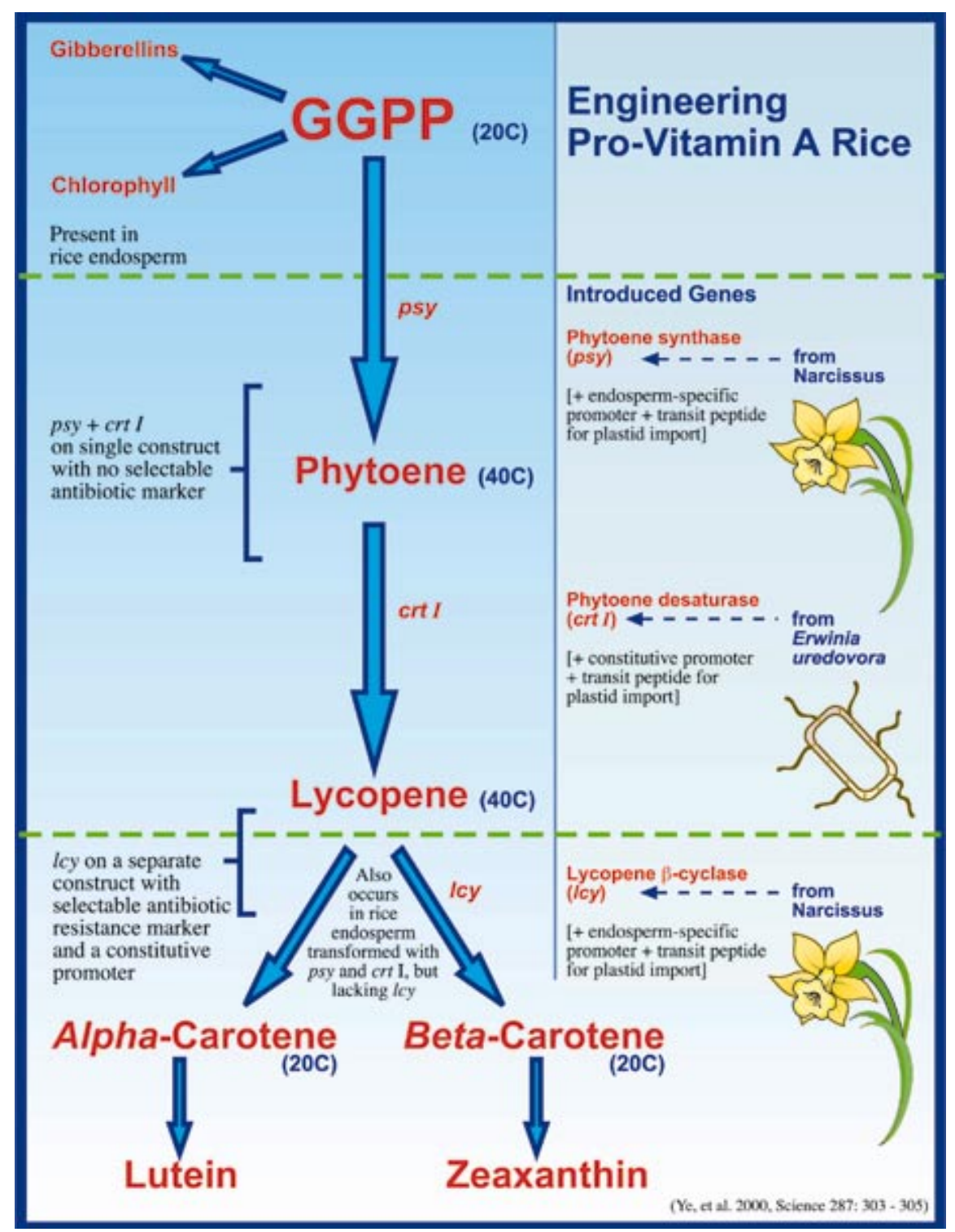

Fig. 6. Steps, sources of genes, and important components of constructs for the development of pro-vitamin A rice.

cance of developing rice with pro-vitamin $\mathrm{A}$ in the endosperm was recognized. For much of his career, P. R. Jennings, a Rockefeller Foundation rice breeder, had been quietly, and without success, looking for yellow endosperm rice that would possibly contain significant levels of betacarotene. Over a beer at the guest house of the International Rice Research Institute (IRRI), he nominated "yellow endosperm" as his favorite trait for improvement using biotechnology because of the likelihood of it carrying the pro-vitamin A, betacarotene. The Rockefeller Foundation financed a systematic survey of the extensive global rice germ plasm collection at IRRI that did not yield any rice accessions with yellow endosperm (G. Toenniessen, personal communication). Subsequently, research was initiated by Ingo Potrykus and a large number of colleagues (50) to engineer rice to synthesize beta-carotene in the endosperm.

It would be difficult to overstate the magnitude of the challenge to engineer rice to accumulate vitamin A precursors in the endosperm (Fig. 6) (85). Biosynthesis of the 20-carbon beta-carotene involves multiple steps, and at the time the project was initiated, transformations for processes typically involved only a single novel reaction. Second, the precursor to carotenoids, the 20-carbon geranyl geranyl diphosphate (GGPP), is present in endosperm of immature seeds. However, it is also the precursor, via the isoprenoid pathway, of other compounds, such as chlorophyll and the gibberellins, that are essential for seed germination and early seedling growth. It was unknown how diverting a portion of GGPP to beta-carotene synthesis would affect germination and early seedling vigor (20).

In plants, four enzymatic steps are required to synthesize 40-carbon betacarotene from GGPP. The carotene phytoene is synthesized from two GGPP in a reaction catalyzed by phytoene synthase. Then two successive reactions incorporate two double bonds each into the phytoene molecule to produce lycopene. Lycopene is then cyclized in a subsequent step to produce beta-carotene. The first step, phytoene synthesis in rice endosperm, was achieved in rice endosperm in 1997 (6). The gene for phytoene synthase from daffodil (Narcissus pseudonarcissus), along with either constitutive or endospermspecific promoters, was incorporated into a rice variety, and seeds were found to accumulate phytoene in the endosperm.

To overcome the problem of multiple transformation events being required to complete the reaction from phytoene to lycopene, the group (85) first took advantage of a bacterial phytoene desaturase from Erwinia uredovora that incorporates all the four required double bonds. Using Agrobacterium-mediated transformation, they introduced the entire beta-carotene 
pathway in one transformation event involving two constructs. One plasmid carried phytoene synthase and phytoene desaturase, in the absence of a selectable antibiotic marker. The phytoene synthase is driven by an endosperm-specific promoter, while the phytoene desaturase is controlled by a constitutive promoter, and cDNAs for both included transit peptides for plastid import that were intended to localize synthesis of lycopene to endosperm plastids where GGPP is found. The second plasmid carried lycopene beta-cyclase that catalyzes the final step of beta-carotene synthesis, controlled by endosperm-specific rice glutelin promoter along with a selectable antibiotic (Hygromycin) resistance marker.

Endosperm of rice seed from transformants for the full complement of enzymes exhibited the expected yellow color and was shown to contain varying amounts of beta-carotene. However, a significant finding was that rice transformants for only the first construct did not accumulate lycopene in the endosperm as expected. Rather, they showed beta-carotene as well as two other carotenoids: lutein and zeaxanthin. Apparently enzymes for the synthesis of these carotenoids from lycopene are either constitutively expressed in the endosperm or induced by the presence of lycopene (85). Subsequent breeding and segregation will allow the separation of a potentially problematic selectable antibiotic resistance marker from the beta-carotene phenotype. The accumulation of lutein and zeaxanthin are of interest, as they have benefits beyond those of vitamin A, such as reduction of macular degeneration in elderly patients (70).

Although this work is much-heralded in the press, there is an enormous amount of work required before "golden rice" will be grown by farmers and eaten by consumers. It should also be understood that golden rice will only help supplement daily intake of pro-vitamin A and is not expected to be a sole source of the vitamin (50). The rice variety TP 309 that carries the trait is agronomically unacceptable for virtually the entire rice-growing world. Either the trait will have to be crossed into more acceptable lines or additional lines will have to be generated. In either case, a laborious breeding program will have to be undertaken to develop acceptable lines that are equivalent to the better modern varieties for most other characteristics. There probably will be consumer resistance to a yellow rice, so governments and public health bodies will have to adopt appropriate policies and develop public education campaigns to promote consumption of beta-carotene rice among the poorest strata of society. There are also important food and environmental safety issues that must be addressed. Although it is highly unlikely that beta-carotene rice would be toxic to humans or harmful to the environment, it is important that the appropriate biosafety evaluations be conducted. It will be particularly important to determine whether or not the novel enzymes from daffodil and Erwinia could have allergenic properties, even though they should be present only at very low levels. In most countries, the regulatory framework to accomplish this is not yet in place. Obviously there is now the need to develop appropriate policies to allow acceptance of biosafety and environmental assessments across political boundaries.

The complex intellectual property issues surrounding beta-carotene producing rice were identified by the International Service for the Acquisition of Agri-Biotech Applications (ISAAA). Kryder et al. (30) "deconstructed" the rice described by Ye et al. (85) and analyzed it for "technical property" (e.g., germ plasm, biological materials, such as plasmids) and "intellectual property" (e.g., patent rights). They found at least 15 different technical components that went into the constructs used in the described transformation protocols. Depending on patent laws of a particular country, up to 44 different patents could apply, with around 40 applying in the United States. However, in most riceproducing countries, many fewer patents apply. Fortunately, in a recent letter posted on the World Wide Web (50), Potrykus describes an agreement with the companies involved, and coordinated by Syngenta, to make the technology freely available to breeding programs and all farmers in developing countries with projected earnings from the technology of less than $\$ 10,000$. Within this "Humanitarian Project," Syngenta retains full commercial rights in all countries but will contribute to further "Golden Rice" development from revenues generated in developed countries. This underscores the intellectual property complexities that will face any entity, public or private, attempting to develop a technology of benefit to the world's poor. How will the legal costs associated with untangling an ever-growing web of patents, material transfer agreements, and intellectual property required for product development be absorbed? Indeed, will most countries even be able to establish the legal framework to address these issues for complex technologies?

Groups opposed to agricultural biotechnology have attacked golden rice as a public relations ploy. They further assert that it can do little to alleviate severe effects of vitamin A deficiencies because so little would be produced in the grain and consumers would have to eat impossibly large amounts of rice to meet their vitamin A needs (21). Readers are referred to a thoughtful response to these positions by Gordon Conway, President of the Rockefeller Foundation, also posted on the Greenpeace web site. Although some companies have apparently used golden rice as an example of how biotechnology can benefit the world's poor, it is disingenuous in the extreme to suggest that this project was developed by the private sector as a "Trojan Horse" for gaining acceptance of biotechnology in developing countries. It is indisputable fact that the project was conceived and executed by public sector scientists with public sector funds.

At this time, the amount of pro-vitamin A that varieties will produce is unknown. Establishing this will require a large amount of plant breeding and adaptive agronomy, extensive field trials, probably some further genetic engineering, and almost certainly a number of nutritional studies on different target populations (e.g., children, pregnant women, and lactating mothers) to determine what level of provitamin $\mathrm{A}$ in rice begins to reduce deficiency symptoms. It does not seem appropriate to suggest that such unknowns be grounds for abandoning the technology. Golden rice should rightfully be considered another tool to help alleviate vitamin deficiencies and not be condemned as a complete failure if it fails to meet unrealistic expectations as a magic bullet. Although this rice may never contribute directly to nutrition of the poor, it can be viewed as a harbinger of things to come. It is a "proof of concept" that engineering complex pathways that influence availability of micronutrients is feasible in crop species. Its indirect impact could be enormous as other starchy staples are targeted for similar improvement.

High-iron rice. Rice is also the main staple over much of the world where iron deficiency is common. Iron deficiency is a complex problem that is determined both from the amount of iron ingested and its absorption. In developed countries, most iron is consumed in readily absorbed heme form in meat, eggs, and dairy products. The poor, especially in developing countries, derive most of their dietary iron from plants that carry poorly absorbed nonheme forms (81). Nonheme iron absorption is inhibited by phytic acid, a phosphorus storage compound that is abundant in the endosperm of staple cereals and grain legumes (19). Those foods that do enhance nonheme iron absorption, such as fruits and leafy vegetables, are often unavailable to or unaffordable by the poor (51). Absorption of nonheme plant-derived iron can be improved upon digestion with the addition of cysteine-rich peptides (9).

Two groups have been working to improve the content and bioavailability of iron in rice grain. Both have had success in adding a gene from legumes coding for the iron-storage protein ferritin $(19,33)$ to increase the absolute amount of nonheme iron in the endosperm. Lucca et al. (33) adopted two additional approaches to improve the iron nutritive value of rice: (i) incorporate a heat-stable phytase that degrades phytic acid and (ii) induce overex- 
pression of a cysteine-rich protein (Fig. 7). Both groups were able to show significant increases in ferritin in the grain; however, it is absorption that is important. Lucca et al. (33) incorporated a chimeric phytase gene that encoded a heat-stable phytase from Aspergillus fumigatus and the barley $\beta$-glucanase signal peptide that localized the phytase to the apoplast. Localization of phytase to the apoplast is necessary to prevent disruption of normal phosphorus metabolism in the developing embryo or germinating seed. Only upon cooking, with the resulting disruption of the cell walls and membranes, should phytase and phytic acid be able to interact. They also introduced a cysteine-rich metallothionein-like (MT) protein to improve nonheme iron absorption (9). The ferritin and MT were regulated by the endosperm-specific glutelin promoter.

The complex strategy adopted by Lucca et al. (33) has yielded mixed results so far. Ferritin and iron content in the endosperm increased significantly, and both phytase and MT showed significant accumulation. Unfortunately, although performing well in simulated digestion experiments, the phytase was not as heat-stable as expected. Further development efforts will have to be invested in order to create or identify heatstable phytases that tolerate cooking temperatures and times typical for rice.

Lucca et al. (33) report that they have successfully crossed the high beta-carotene producing rice lines with their high-iron rice lines. As improved vitamin A nutrition has recently been shown to improve iron absorption (16), combining these traits could have an enormous impact on the nutrition of the poor. Likewise, with adequate vitamin A supplied by cereal, the amount of iron required in the diet should be less.

A high-iron rice will face the same difficulties described for vitamin A rice. In addition to allergenicity concerns over the novel enzymes, the accumulation of a novel storage protein not normally encountered in cereals should be evaluated carefully for its allergenic properties.

Reducing toxins and carcinogens in maize. The primary Fusarium species causing ear rot of maize in southern Africa is Fusarium verticillioides (formerly known as $F$. moniliforme). Fusarium-contaminated grain was shown to be toxic to horses early in the twentieth century and has been associated with several diseases of livestock, particularly horses, swine, and poultry (38). An association between esophageal and liver cancer in humans and maize beer consumption was identified in South Africa in the early 1980s $(37,75)$; although, it was suspected earlier (39). Only in the late 1980s were the specific toxins, fumonisins, produced by Fusarium spp. identified (17). Six fumonisins have been identified, with the most toxic, FB1, the best characterized. Fusarium proliferatum (T. Matsushima) Nirenberg and $F$. nygamai Burgess \& Trimboli have also been shown to produce fumonisin FB1 and FB2 (69). Subsequently, fumonisins have been identified as contaminants in food stuffs throughout the world $(62,65,67)$.

With the identification and characterization of the fumonisins, an understanding of the toxigenic ability of the Fusarium species infecting cereal grains began to emerge.

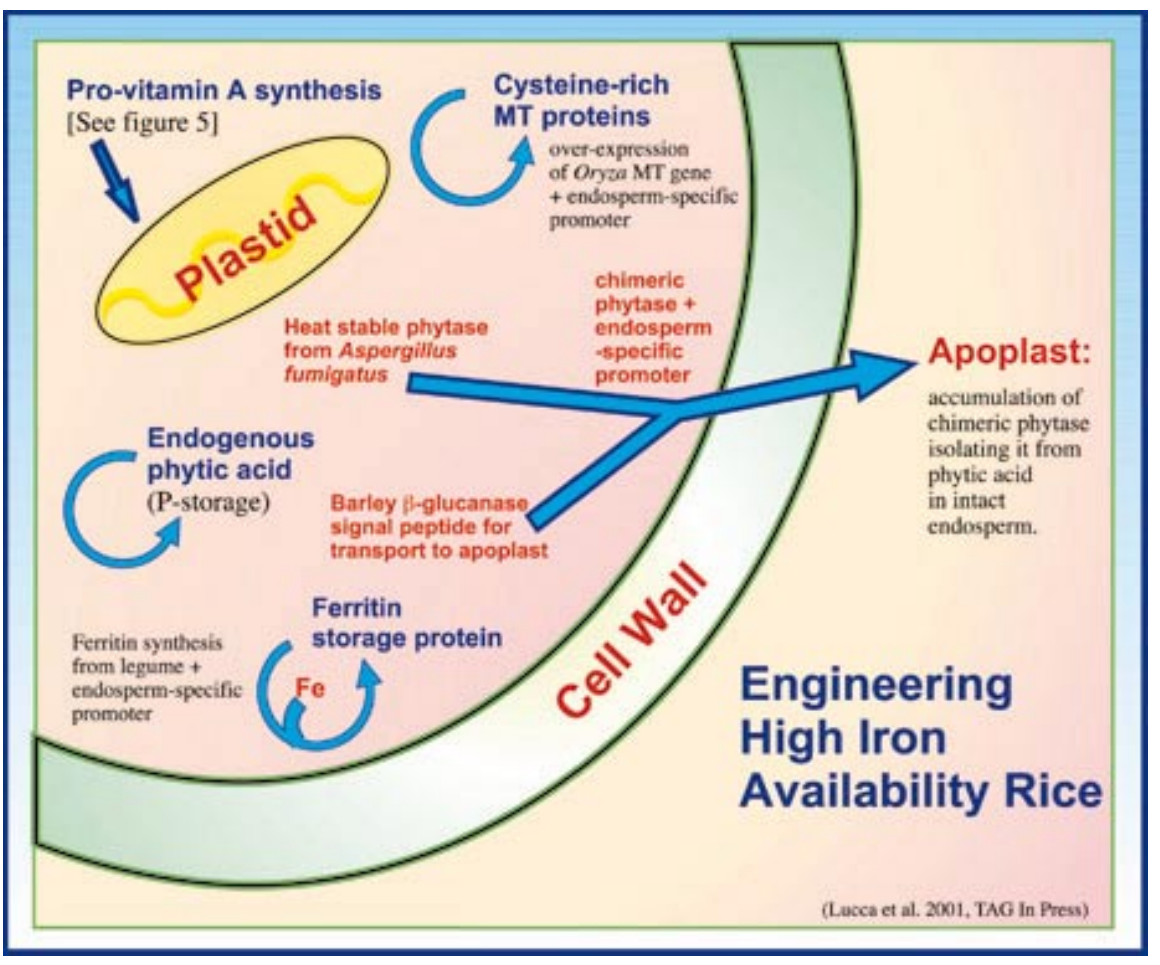

Fig. 7. Modification of rice seed for development of high-iron rice.

A number of studies demonstrated their toxicity and carcinogenic potential in laboratory animals (36). Fumonisin FB1 appears to inhibit sphingolipid biosynthesis in rats, horses, and pigs. Sphingolipids are involved in regulating cell growth and differentiation, which could partially explain fumonisin toxicity and carcinogenesis (41). Several studies in the early 1990s demonstrated a high correlation between recovery of high fumonisin FB1-producing strains from samples of homegrown maize and high esophageal and hepatic cancers $(53,66)$. F. moniliforme strains producing low levels of fumonisin FB1 were typically recovered from maize in areas of South Africa with low esophageal cancer rates. Although causal links between hepatic cancer in rats and fumonisin FB1 exposure have been well-documented, it has been difficult to establish with a high degree of certainty the relationship in humans because of ethical considerations.

Insect damage to maize ears has been associated with ear rotting fungi, including Fusarium spp. (77). The literature discussing Fusarium-induced ear rot in maize in South Africa does not specifically mention insect feeding damage being associated with moldy ears. However, while working with maize in east-central Africa in the 1980s, I observed a close correspondence between the two. Both field and greenhouse experiments in the Corn Belt of the United States demonstrated that F. moniliforme can be transmitted to healthy ears by the European corn borer, causing grain molding and symptomless infection $(43,64)$. The European corn borer is the primary insect pest targeted for control by maize transformed with Cry proteins from the bacterium Bacillus thuringiensis. Cry protein-transformed maize (Bt maize) was grown on $33 \%$ of U.S. maize area, or over 10 million ha in 1999, suggesting that farmers view it as an effective agent to control intransigent stalk boring insects (26).

Munkvold et al. (45) demonstrated that manually infected and field-infected $\mathrm{Bt}$ maize hybrids showed significantly less insect feeding damage and kernel infection by Fusarium spp. (primarily F. moniliforme) than did near-isogenic nontransformed hybrids. An analysis of fumonisin content of kernels in manually infected and field-infected maize hybrids revealed consistently higher levels of fumonisin B1, as well as B2 and B3, in non-Bt maize hybrids than in Bt maize hybrids (44). The effectiveness depended on the particular transformation event and the specific Cry protein involved.

The Bt maize technology that is now reaping benefits for U.S. maize growers is clearly a technology that is immediately available for use in Africa. It appears that there is the potential for a major societal benefit beyond the intended reduction of losses to stalk and ear feeding insects. This 
should serve as a concrete example of an unintended side effect of transgenic crop technology benefiting poor consumers.

\section{The Future}

Agricultural biotechnology applications in developing countries have the potential to mitigate some of the most difficult problems facing poor farmers and consumers. By enhancing agricultural productivity through reduced losses to diseases and pests and, eventually, by increasing yield potential of major crops, we can help reduce the real cost of food while preserving or increasing farmer income. For the very poor, these reduced prices will translate directly into increased disposable income. There is good evidence that the severe problems of malnutrition caused by shortages in essential vitamins and minerals can be mitigated by engineering staple crops to produce these at dietarily significant levels. Such crops can play an important role in integrated social programs designed to eliminate dietary deficiencies in the poor.

An attractive aspect of transgenic technologies is that once they are incorporated into a breeding program, they can be managed much like any other trait. After the initial product development and assessment, existing plant breeding programs can incorporate the traits into material suitable to the particular requirements and environmental conditions of its target farmers and agroecosystems. Thus, it is not necessary in the short term for developing countries wishing to take advantage of transgenic technology to mount full-scale molecular biology and breeding programs. Likewise, depending on the technology, farmers may be able to continue to use it without increasing their frequency of seed purchase.

The development and deployment of transgenic crops in developing countries will require policy adjustments at several levels. First, very clear biosafety assessment and environmental impact evaluation protocols will have to be developed. It is essential that novel products be evaluated for consumer safety, especially for the presence of allergens and potential toxins. Such testing need not be carried out by every country; however, clear guidelines for accepting results obtained in other countries will have to be worked out. Likewise, assessment of environmental impact should be undertaken, with the understanding that no agricultural technology is without environmental impact. This will require not only adequate regulatory expertise within each country, but the political will to devote adequate resources to this.

In the politically charged atmosphere currently surrounding transgenic crop technology, it will be essential that the regulatory framework be science-based and of appropriate rigor for it to maintain its credibility. For a number of developing countries, creating the transgenic crops assessment infrastructure may be practically impossible (5). In such cases, regional networks and programs may be the most cost-effective means to achieve this. There are agricultural research centers around Africa, for example, that could serve as regional technology assessment centers. Countries such as Egypt, Ivory Coast, Kenya, Nigeria, South Africa, and Zimbabwe have distinguished histories in agricultural research and host international agricultural research centers (78). Likewise, in Asia and Latin America, countries such as India, China, the Philippines, Brazil, and Mexico could readily help lead regional testing, evaluation, and policysetting programs (56). With clear guidelines, safety for human consumption could be judged based on data and regulatory decisions from wealthier countries with well-established testing, evaluation, and acceptance procedures and policies.

Intellectual property limits are important policy constraints to adoption of these technologies, especially their incorporation into germ plasm adapted to local conditions (15). The entire agricultural biotechnology industry is still working out how to handle the myriad of patents, licenses, etc., that now permeate even the more simple procedures and intermediate technologies. The effort to free beta-carotene rice from these constraints is a promising step. Hopefully, this will serve as a guiding principle for the entire industry: free access to technology for product development likely to be of significant benefit to the poor in developing countries, while maintaining proprietary interests in the same products deployed in developed countries.

Agricultural biotechnology cannot solve all of the problems confronting developing countries. Some of its products will be tools that can help solve some of the most serious constraints to economic development and poverty alleviation. It is critical that these tools not be viewed as magic bullets that can replace essential progress in basic crop improvement, and crop and natural resource management. It is especially important that policymakers see these technologies as complements to needed investments in social infrastructure.

\section{Acknowledgments}

I thank Jennifer Foltz for her creative graphics design work. E. Carey provided valuable background information on the status of sweet potato improvement in eastern Africa.

\section{Literature Cited}

1. Agarie, S., Tsuchida, H., Ku, M., Nomura, M., Matsuoka, M., and Miyao-Tokutomi, M. 1998. High level expression of C4 enzymes in transgenic rice plants. Pages 3423-3426 in: Photosynthesis: Mechanisms and Effects. Vol. V. G. Garab, ed. Kluwer, Dordrecht, Netherlands.
2. Anonymous. 2000. Can Africa Claim the 21st Century? World Bank, Washington, DC.

3. Aritua, V., Adipala, E., Carey, E. E., and Gibson, R. W. 1998. The incidence of sweet potato virus disease and virus resistance of sweet potato grown in Uganda. Ann. Appl. Biol. 132(3):399-411.

4. Aritua, V., Alicai, T., Adipala, E., Carey, E. E., and Gibson, R. W. 1998. Aspects of resistance to sweet potato virus disease in sweet potato. Ann. Appl. Biol. 132(3):387-398.

5. Brink, J., Woodward, B., and DaSilva, E. 1998. Plant biotechnology: A tool for devel-

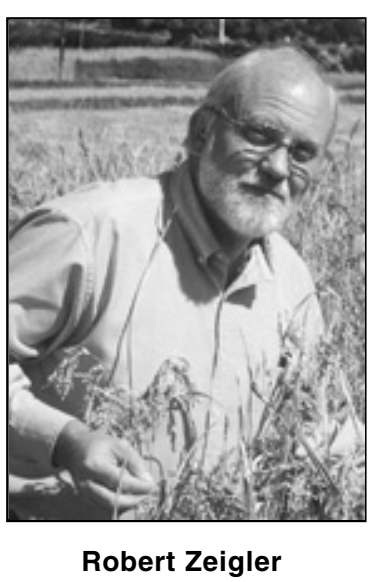

Robert Zeigler earned his B.Sc. from the University of Illinois in 1972, after which he joined the Peace Corps and taught high school science in a small school in rural Zaire. Upon return from Zaire, he married Crissan and subsequently earned an M.Sc. from Oregon State University in botany and plant pathology (forest ecology), then a Ph.D in plant pathology from Cornell University. His doctoral thesis was on the Superelongation disease of cassava, with the field work conducted at the Centro Internacional de Agricultura Tropical (CIAT) in Cali, Colombia. Following completion of his Ph.D., he moved with his family to Burundi, where he headed a small maize improvement program for about 3 years. In 1985, the family moved back to Cali to take a position at CIAT, where Bob served as rice pathologist for 7 years and as rice program leader from 1986 to 1992. His research focused on Rice hoja blanca virus (RHBV), bacterial sheath brown rot of rice, and especially rice blast disease. In 1992, Dr. Zeigler took a position as pathologist and program leader at the International Rice Research Institute in the Philippines. There, his research focused on rice blast disease, and he was able to test a number of hypotheses related to the nature of durable resistance and population structure and dynamics of the blast pathogen in traditional rice-growing environments. In 1999, the Zeigler family moved to Manhattan, KS, after he took up the position of head of the Department of Plant Pathology and director of the Plant Biotechnology Center at Kansas State University. 
opment in Africa. EJB Electronic J. Biotechnol. 1:1-10.

6. Burkhardt, P. K., Beyer, P., Wunn, J., Kloti, A., Armstrong, G. A., Schledz, M., von Lintig, J., and Potrykus, I. 1997. Transgenic rice (Oryza sativa) endosperm expressing daffodil (Narcissus pseudonarcissus) phytoene synthase accumulates phytoene, a key intermediate of provitamin A biosynthesis. Plant J. 11(5):1071-1078.

7. Campbell, R. N., and Nienhaus, F. 1989. Sweet potato feathery mottle potyvirus. Plant Viruses Online.

8. Conway, G. 1997. The Doubly Green Revolution. Cornell University Press, Ithaca, NY.

9. Cook, J., Reddy, M., Burri, J., Juillert, M., and Hurrell, R. 1997. The influence of different cereal grains on iron absorption from infant cereal foods. Am. J. Clin. Nutrition 65:964-969.

10. Dawe, D. 2000. The contribution of rice research to poverty alleviation. Pages 3-12 in: Redesigning Rice Photosynthesis to Increase Yield. J. E. Sheehy, P. L. Mitchell, and B. Hardy, eds. Elsevier Science B.V., Amsterdam, The Netherlands.

11. Deaton, A. 1997. The Analysis of Household Surveys. Johns Hopkins Press, Baltimore, MD.

12. Dobermann, A., Dawe, D., Roetter, R., and Cassman, K. 2000. Reversal of Rice Yield Decline in a Long-Term Continuous Cropping Experiment. Agron. J. 92:633-643.

13. Evenson, R., Pray, C., and Rosegrant, M. 1999. Agricultural research and productivity growth in India. Res. Rep. 19. International Food Policy Research Institute, Washington, DC.

14. FAO. 2000. FAOSTAT DATA. Food and Agriculture Organization of the United Nations. Published on-line.

15. Fischer, K., Barton, J., Khush, G., Leung, H., and Cantrell, R. Collaborations in rice. Science 290:279-280.

16. Garcia-Casal, M. N., Layrisse, M., Solano, L., Baron, M. A., Arguello, F., Llovera, D., Ramirez, J., Leets, I., and Tropper, E. 1998. Vitamin A and beta-carotene can improve nonheme iron absorption from rice, wheat and corn by humans. J. Nutr. 128(3):646-650.

17. Gelderblom, W., Jaskiewicz, K., Marasas, W., Theil, P., Horak, R., Vleggaar, R., and Kriek, N. 1988. Fumonisins-Novel mycotoxins with cancer-promoting activity produced by Fusarium moniliforme. Appl. Environ. Microbiol. 54:1806-1811.

18. Gonsalves, D. 1998. Control of papaya ringspot virus in papaya: A case study. Annu. Rev. Phytopathol. 36:415-437.

19. Goto, F., Yoshira, T., Saiki, H., Toki, S., and Takaiwa, F. 1999. Iron fortification of rice seed by the soybean ferritin gene. Nature Biotechnol. 17:282-286.

20. Guerinot, M. L. 2000. Enhanced: The green revolution strikes gold. Science 287(5451):241-243.

21. Haerlin, B. 2001. GE rice is fool's gold. Greenpeace. Published on-line.

22. Hazell, P., and Ramasamy, S., eds. 1991. The Green Revolution Reconsidered: The Impact of High-Yielding Rice Varieties in South India. Johns Hopkins University Press, Baltimore, MD.

23. Horton, P., and Murchie, E. 2000. C4 photosynthesis in rice: Some lessons from studies of C3 photosynthesis in field-grown rice. Pages 127-144 in: Redesigning Rice Photosynthesis to Increase Yield. J. E. Sheehy, P. L. Mitchell, and B. Hardy, eds. Elsevier Science B.V., Amsterdam, The Netherlands.

24. Hossain, M. 1996. Recent Developments in the Asian Rice Economy: Challenges for Rice Research. Pages 17-33 in: Rice Research in
Asia: Progress and Priorities. R. E. Evenson, R. W. Herdt, and M. Hossain, eds.

25. Ives, C. L., and Wambugu, F. Agricultural biotechnology: Current and future trends and implications for Africa. In: Perspectives on Agricultural Transformation: A View from Africa. T. S. Jayne, G. Argwings-Kodhek, and I. Minde, eds. Nova Science Publishers, New York. In press.

26. James, C. 1999. Global status of commercialized transgenic crops: 1999. ISAAA Briefs No. 17. International Service for the Acquisition of Agri-Biotech Applications, Ithaca, NY.

27. Johanson, A., and Ives, C. 2000. An inventory of agricultural biotechnology for the Eastern and Central African region. Institute of International Agriculture, Michigan State University, East Lansing.

28. Karyeija, R. F., Gibson, R. W., and Valkonen, J. P. T. 1998. Resistance to sweet potato virus disease (SPVD) in wild East Africa Ipomoea. Ann. Appl. Biol. 133(1):39-44.

29. Kropff, M., Cassman, K., Peng, S., Matthews, R., and Setter, T. 1994. Quantitative understanding of yield potential. Pages 21-38 in: Breaking the Yield Barrier. K. Cassman, ed. International Rice Research Institute, Manila, Philippines.

30. Kryder, R., Kowalski, S., and Krattiger, A. 2000. The Intellectual and Technical Property Components of pro-Vitamin A Rice (GoldenRice $\left.^{\mathrm{TM}}\right)$ : A Preliminary Freedom-To-Operate Review. ISAAA Briefs No. 20. International Service for the Acquisition of Agri-Biotech Applications, Ithaca, NY.

31. Ku, M. S. B., Cho, D., Ranade, U., Hsu, T. P., Li, X., Jiao, D. M., Ehleringer, J., Miyao, M., and Matsuoka, M. 2000. Photosynthetic performance of transgenic rice plants overexpressing maize $\mathrm{C} 4$ photosynthesis enzymes. Pages 193-206 in: J. E. Sheehy, P. L. Mitchell, and B. Hardy, eds. Redesigning Rice Photosynthesis to Increase Yield. Elsevier Science B.V., Amsterdam, The Netherlands.

32. Leegood, R. C. 2000. Overcoming barriers: $\mathrm{CO}_{2}$-concentrating mechanisms and $\mathrm{C} 4 \mathrm{me}$ tabolism in relation to transport. Pages 113126 in: Redesigning Rice Photosynthesis to Increase Yield. J. E. Sheehy, P. L. Mitchell, and B. Hardy, eds. Elsevier Science B.V., Amsterdam, The Netherlands.

33. Lucca, P., Hurrell, R., and Potrykus, I. 2001. Genetic engineering approaches to improve the bioavailability and the level of iron in rice grains. Theor. Appl. Genet. In press.

34. Maberly, G., Trwobridge, F., Yipp, R., Sullivan, K., and West, C. 1994. Programs against micronutrient malnutrition: Ending hidden hunger. Annu. Rev. Public Health 15:277-301.

35. Maclean, J., and Rola, T. 1997. Rice Almanac. 2nd ed. International Rice Research Institute, Los Banos, Philippines.

36. Marasas, W. 1996. Fumonisins: History, world-wide occurrence and inpact. Pages 1-17 in: Fumonisins in Food. L. Jackson, ed. Plenum Press, New York.

37. Marasas, W., Jaskiewicz, K., Venter, F., and van Schalkwyk, D. 1988. Fusarium moniliforme contamination of maize in oesophageal cancer areas in Transkei. S. Afr. Med. J. 74:110-114.

38. Marasas, W., and Nelson, P. 1987. Mycotoxicology. Pennsylvania University Press, College Park.

39. Marasas, W., Wehner, F., van Rensberg, S., and Schlkwyk, D. 1981. Mycoflora of corn produced in human esophageal cancer areas in Transkei, Southern Africa. Phytopathology 71:792-796.

40. Matsuoka, M., Fukayama, H., Tsuchida, H., Nomura, M., Agarie, S., Ku, M. S. B., and Miyao, M. 2000. How to express some C4 photosynthesis genes at high levels in rice.
Pages 167-175 in: Redesigning Rice Photosynthesis to Increase Yield. J. E. Sheehy, P. L. Mitchell, and B. Hardy, eds. Elsevier Science B.V., Amsterdam, The Netherlands.

41. Miller, J., and Trenholm, H. 1994. Mycotoxins in grain: Compounds other than aflatoxins. Eagan Press, St. Paul, MN.

42. Moyer, J. W. 1989. Sweet potato feathery mottle potyvirus. Plant Viruses Online. Published on-line.

43. Munkvold, G. P., and Desjardines, A. E. 1997. Fumonisins in maize: Can we reduce their occurrence? Plant Dis. 81:556-565.

44. Munkvold, G. P., Hellmich, R. L., and Rice, L. G. 1999. Comparison of fumonisin concentrations in kernels of transgenic Bt maize hybrids and nontransgenic hybrids. Plant Dis. 83:130-138.

45. Munkvold, G. P., Hellmich, R. L., and Showers, W. B. 1997. Reduced Fusarium ear rot and symptomless infection in kernels of maize genetically engineered for European corn borer resistance. Phytopathology 87:1071-1077.

46. Musau, Z. 2000. Genetically Modified Sweet Potato Launched in Kenya. The Nation (Nairobi). August 19, 2000

47. Paarlberg, R. 2000. Governing the GM crop revolution: Policy choices for developing countries. Food Agriculture and the Environment Discussion Paper 33. International Food Policy Research Institute, Washington, DC.

48. Paddock, W., and Paddock, P. 1967. Time of famines. Little, Brown, Boston, MA.

49. Pinstrup-Andersen, P., Pandya-Lorch, R., and Rosegrant, M. W. 1999. World Food Prospects: Critical Issues for the Early TwentyFirst Century. Food Policy Report 30. International Food Policy Research Institute, Washington, DC.

50. Potrykus, I. 2000. The "Golden Rice" tale. AgBioView: Home Page: Archive. Message \#906. Published on-line.

51. Rahman, M., Mahalanabis, D., Islam, M., and Biswas, E. 1993. Can infants and young children eat enough green leafy vegetables from a single traditional meal to meet their daily viamin A requirements? Eur. J. Clin. Nutrition 47:68-72.

52. Reiskind, J., Madsen, T., van Ginkel, L., and Bowes, G. 1997. Evidence that inducible C4 type photosynthesis is a chloroplastic $\mathrm{CO}_{2}$ concentrating mechanism in Hydrilla, a submerged monocot. Plant Cell Environ. 20:211 220.

53. Rheeder, J., Marasas, W., Thiel, P., Sydenham, E., Shephard, G., and van Schalkwyk, D 1992. Fusarium moniliforme and fumonisins in corn in relation to human esophageal cancer in Transkei. Phytopathology 82:353-357.

54. Rheeder, J., Marasas, W., van Wyk, P., and van Schalkwyk, D. 1990. Reaction of South African maize cultivars to ear inoculations with Fusarium moniliforme, $F$. graminearum, and Diplodia maydis. Phytophylactica 22:213-218.

55. Sage, R. F. 2000. C3 versus C4 photosynthesis in rice: Ecophysiological perspectives. Pages 13-35 in: Redesigning Rice Photosynthesis to Increase Yield. J. E. Sheehy, P. L. Mitchell, and B. Hardy, eds. Elsevier Science B.V., Amsterdam, The Netherlands.

56. Sahai, S. 1999. Biotechnology capacity of LDCs in the Asian Pacific Rim. AgBioForum, 2:189-197. Published on-line.

57. Saito, A., Kimura, T., Ideta, O., Mori, M., and Nishiguchi, M. 1998. Transgenic sweet potato (Ipomoea batatas L. (Lam)) exhibiting resistance to sweet potato feathery mottle potyvirus. Sweet Potato Res. Front 7:4.

58. Serageldin, I., and Persley, G. 2000. Promethean science: Agricultural biotechnology, the environment, and the poor. Consultative 
Group on International Agricultural Research, Washington, DC

59. Shang, Y. F., Yang, C. L., Xin, X. Q., Zhao, J. H., Li, C. S., Luo, R. W., Shang, Y. F., Yang, C. L., Xin, X. Q., Zhao, J. H., Li, C. S., and Luo, R. W. 1996. Technique for virus-free sweet potato production by meristem tip culture. Plant Prot. 22(5):14-16.

60. Sharma, R., and Poleman, T. 1994. The new economics of India's green revolution: Income and employment diffusion in Uttar Pradesh. Vikas, New Delhi, India.

61. Sheehy, J. E. 2000. Limits to yield for C3 and C4 rice: An agronomists view. Pages 39-52 in: Redesigning Rice Photosynthesis to Increase Yield. J. E. Sheehy, P. L. Mitchell, and B. Hardy, eds. Elsevier Science B.V., Amsterdam, The Netherlands.

62. Shephard, G., Thiel, P., Stockenstrom, S., and Sydenham, E. 1996. Worldwide survey of fumonisin contamination of corn and cornbased products. J. AOAC Int. 79:671-687.

63. Smith, L., and Haddad, L. 2000. Explaining Child Malnutrition in Developing Countries: A Cross-Country Analysis. International Food Policy Resarch Institute, Washington, DC.

64. Sobek, E., and Munkvold, G. 1999. European corn borer (Lepidoptera:Pyralidae) larvae as vectors of Fusarium moniliforme, causing kernal rot and symptomless infection of maize kernels. J. Econ. Entomol. 92:503-509.

65. Syndenham, E., Shephard, G., Thiel, P., Marasas, W., and Stockenstrom, S. 1991. Fumonisin contamination of commercial cornbased human foodstuffs. J. Agric. Food Chem. 39:2014-2018.

66. Sydenham, E., Thiel, P., Marasas, W., Shephard, G., Schalkwyk, D., and Koch, K. 1990. Natural occurrence of some Fusarium mycotoxins in corn from low and high eso- phageal cancer prevalence areas of the Transkei, Southern Africa. J. Agric. Food Chem. 38:1900-1903.

67. Sydenham, E., Glederblom, W., Thiel, P., and Marasas, W. 1990. Evidence for the natural occurrence of fumonisin B1, a mycotoxin produced by Fusarium moniliforme, in corn. J. Agric. Food Chem. 38:285-290.

68. Taylor, W. 2000. C4 rice: What are the lessons from development and molecular studies? Pages 87-98 in: Redesigning Rice Photosynthesis to Increase Yield. J. E. Sheehy, P. L. Mitchell, and B. Hardy, eds. Elsevier Science B.V., Amsterdam, The Netherlands.

69. Thiel, P., Marasas, W., Sydenham, E., Shephard, G., Glederblom, W., and Nieuwenhuis, J. 1991. Survey of fumonisin production by Fusarium species. Appl. Environ. Microbiol. 57:1089-1093.

70. UNICEF. 1997. Vitamin A global initiative: A strategy for acceleration of progress in combating vitamin A deficiency. United Nations, New York.

71. UNICEF. 1998. The State of the World's Children. Oxford University Press, Oxford

72. UNICEF. 2000. The State of the World's Children. Oxford University Press, Oxford.

73. UNICEF. 2000. Vitamin A deficiency - A cause of child death that can be easily prevented. Vitamin A-Global Initiative. United Nations, New York.

74. United Nations. 1998. World urbanization prospects: The 1998 revision. United Nations, New York.

75. Van Resenberg, S. 1985. Recent studies on the etiology of oesophageal cancer. S. Afr. Cancer Bull. 29:22-31.

76. Wambugu, F. 2000. The role of GMOs in feeding developing countries: ISAAA AfriCenter case studies and experience in sub-
Saharan Africa. International Service for the Acquisition of Agri-Biotech Applications, Ithaca, NY.

77. White, D. G., ed. 1999. Compendium of Corn Diseases. 3rd ed. American Phytopathological Society, St. Paul, MN.

78. Woodward, B., Brink, J., and Berger, D. 1999. Can agricultural biotechnology make a difference in Africa? 2:175-181. Published on-line.

79. World Bank. 2000. World Development Report. The World Bank, Washington, DC.

80. World Health Organization. 1995. Global prevalence of vitamin A deficiency. Micronutrient Deficiency Information System Working Paper 2. United Nations, New York.

81. World Health Organization. 2000. Battling iron deficiency anemia. United Nations, New York. Published on-line.

82. Yang, C. 1980. Research on esophageal cancer in China: A review. Cancer Res. 40:26332644.

83. Yang, C. L., Shang, Y. F., Zhao, J. H., Li, C. S., Yang, C. L., Shang, Y. F., Zhao, J. H., and Li, C. S. 1998. Produce techniques and practice of virus-free sweet potato. ActaPhytophylactica-Sinica 25(1):51-55.

84. Yang, Y. J., Xin, J. Y., Wu, J. Y., and Lu, G. Q 1993. Preliminary study of sweet potato virus diseases in China. Pages 130-134 in: Proc. Asia Sweet Potato Germplasm Network Meeting, Guangzhou, China.

85. Ye, X., Al-Babili, S., Kloti, A., Zhang, J., Lucca, P., Beyer, P., and Potrykus, I. 2000. Engineering the Provitamin A (B-Carotene) Biosynthetic Pathway into (Carotenoid-Free) Rice Endosperm. Science 287:303-305.

86. Zeigler, R., and Puckridge, D. 1995. Improving sustainable productivity in rice-based rainfed lowland systems of South and Southeast Asia. GeoJournal 35:307-324. 